Cinémas

Revue d'études cinématographiques

Journal of Film Studies

\title{
GAINES, Jane, HERZOG, Charlotte (eds). Fabrications: Costume and the Female Body. New York: Routledge, 1990, 295 p.
}

\section{Sandra Niessen}

Volume 3, numéro 2-3, printemps 1993

URI : https://id.erudit.org/iderudit/1001202ar

DOI : https://doi.org/10.7202/1001202ar

Aller au sommaire du numéro

Éditeur(s)

Cinémas

ISSN

1181-6945 (imprimé)

1705-6500 (numérique)

Découvrir la revue

Citer ce compte rendu

Niessen, S. (1993). Compte rendu de [GAINES, Jane, HERZOG, Charlotte (eds)

Fabrications: Costume and the Female Body. New York : Routledge, 1990, 295 p.]

Cinémas, 3(2-3), 247-251. https://doi.org/10.7202/1001202ar d'utilisation que vous pouvez consulter en ligne.

https://apropos.erudit.org/fr/usagers/politique-dutilisation/ 
GAINES, Jane, HERZOG, Charlotte (eds). Fabrications: Costume and the Female Body. New York : Routledge, 1990, 295p.

The study of clothing and bodily decoration has traditionally been the purview of costume historians and, to a lesser extent, anthropologists and sociologists. The 11 contributing authors of this volume hail from departments of English, Communications, Art, Sociology, Theatre and Film. Together they describe new terrain for the study of the presentation and representation of the female.

One of the most important contributions feminist film theory has made to the larger field of feminist inquiry has been the argument that the image of woman is a "construction". (1)

With this single opening sentence, Jane Gaines sets out the parameters of the volume, its heritage and its legacy ("Introduction : Fabricating the Female Body"). In the first instance, the collection of essays is a feminist contribution to film studies. Second, the "construction" of the female image is a multi-faceted concept ranging from the physical construction of the costume (designing, sewing) and the body (weight-training, demeanor), to the ideological construction both on the part of the clothing bearer (consumer of images, "movie-star" producer of images) and the observer (male or female). The central focus of the book - costume in cinema - cannot but embrace issues of the fabrication of the female and the feminine in general.

Fashion is inevitable. Fabrications are inescapable. Despite rebellion against them, masks cannot be stripped off; there is no extra-societal existence; anti-fashion is also fashion. "We long for a sartorial nirvana in which fashion - which expresses the change that is life - would be no more" (38). Elizabeth Wilson's opening chapter ("All the Rage") impresses the reader with the profundity of the ever-present theme of costume and body which, while as an industry it lines many pockets and as a focus of consumption depletes many others, nevertheless has never received fair academic due.

It is not that clothes make the woman. They adorn her and interact with her in a variety of ways. In consuming fashion images, she is consuming images of femaleness, including her body and her demeanor : 
The fashion show within the film and its presentation style also taught women how to look and act like mannequins. It could be said that high fashion clothes dictate a particular behavior and comportment. The slung-out hip; the affected, delicate, limp hand; the third ballet position of the feet; and the tilted-back head, all suggest high style couture (...) (Charlotte Herzog's "Powder Puff" Promotion : The Fashion Show-in-the-Film, 150).

Concern is not merely for whether clothing fits the body, but whether the body fits the clothing. If costume is a mask, underneath the costume is yet another mask. Laurie Schulze's analysis of responses to, and characterizations of muscular females ("On the Muscle") is a reminder of how the ideal image of the female body has its own fashion history. If this were not so, the bodybuilder female would not present an "ideological strain," taxing notions of sex, gender, and sexuality with her "pumped up" muscles and her hard, ripped body. In occupying domains for which there are no categories, she is described as "unnatural," an impossibility, a perversion, an impostor.

If this is an oppositional body, most of the rest of this volume deals with the compliant body, and conforming femininity constructed by, for, and with social approval. The statue of Liberty is a monumental example. Serafina K. Bathrick ("The Female Colossus : The Body as Facade and Threshold") dismembers her to brilliantly recall the social conditions that originally put her together. Liberty, and her many sisters reside in the heights of the central buildings of the American nation, representing the "domestic True Woman ideal (...) widely represented in women's magazines (...) representing in plaster the hopes for a nation which was losing its sense of commmunity and its relationship to handcrafted culture" (84). These monumental women straddle the social crisis which attends the transition from artisanal process to modern industrial mode of production. They "humanize industrial life" (82); they present the "opportunity to recall momentarily the experience feared lost to the age of industry" (99). The monumental woman is mother; she is nurturer; her clothing hangs in folds, draped gently over her body obscuring any hint of sexuality.

While Mythical Woman was presiding over the nation with her gentle, kind image of humanist values, Real Woman was taking up her image struggle in the new industrial climate. The editors have reprinted in this volume the well-written classic by Charles Eckert, "The Carole Lombard in Macy's Window" (originally published in 1978) which documents the "almost incestuous hegemony that characterized Hollywood's relations with vast reaches of the American economy" (103). The movies, 
empowered by manufacturers' dollars, proffered powerful images of material wealth to their viewers and manufacturers responded to the demand. So close was this relationship that the fine line between feature film and advertisement became increasingly fuzzy and finally disappeared altogether. Fashionable women shopped in Cinema Fashions Shops (Macy's contracted for the first in 1930), purchased Carole Lombard's dresses and "gowns and suits worn by Pauline Lord, Lynne Fontaine, Frieda Innescourt, Sylvia Fields, and Murial Kirkland" (107), cosmetics worn by Janet Gaynor...

"Were there women in that era of strained expectations married women entering the labor force when the gap was widening between men's and women's salaries, but advertising was increasingly pitched at women consumers - for whom the contradictions may have reached the breaking point?" (133) asks Jeanne Thomas Allen ("Fig Leaves in Hollywood : Female Representation and Consumer Culture"). The film, Fig Leaves, inspired the question. It is a tale about the difficulty of consuming when the means are insufficient, and it puts across a message about "appropriate" feminine behavior. Hollywood is wooing women through their consumer urges and teaching them at the same time to rely on their man, rather than their own ingenuity to satisfy those urges.

Similarly, in consuming clothing, women are consuming more than tailored fabric. It is not fortuitous, claims Maureen Turim ("Designing Women : The Emergence of the New Sweetheart Line") that the sweetheart line - tightly fitting bodice, and wide, loosely flowing skirt - is the symbol for the women's toilet, contrasted with the male outline. It is exaggerated feminine : fluffy layering in ruffles and folds around the woman's sexual organs.

Just as these decorative dresses were often very uncomfortable and impractical to wear, so the decorative and passive function assigned to women by their metaphorical inscription in such clothing was the ugly underside of the charming appearance (....) This style, by enforcing symbolic femininity, allowed for a great restriction of the female role to be attached to the very notion of the feminine (227).

The complexities of the purchase of a feminine image are well addressed by various chapters in Fabrications. Images are interpreted by both genders in similar, complementary, and opposing ways. Modeling by a married woman, stresses "Fig Leaves", is prostitution and is portrayed as disloyalty to the husband. What is being sold, asks Charlotte Herzog, in the early 
films of this century which incorporate the fashion show? Both men and women viewers are "purchasing" the goods of movie sale. The key here is that the models are not simply modeling clothing, but are modeling their bodies. They are being "consumed" by male viewers as a complete package. ("Where else but at the movies could a working-class man see a fashion show and vicariously "buy" the models for the price of admission?", 157). Are women consumers, therefore, "buying clothes to get bought, or just to get a man, period (...)? Men wore women on their arms for status the way women wore clothes on their backs" (p.158).

Gaylyn Studlar notes that Freudian interpretation of film has failed to adequately address the significance of costume. Taking Marlene Dietrich's costumes as fetish, ("Masochism, Masquerade, and the Erotic Metamorphoses of Marlene Dietrich") in the sense intended by Deleuze's theory of masochism, she pieces together an interpretation of the psychological effects, on men, of costumes : fur, feathers, etc. The complement, in a sense, to this exercise, is Angela McRobbie's study of currently popular films about dance ("Fame, Flashdance, and Fantasies of Achievement"), items of popular culture which appeal especially to women. It is time to take dance, too, into account, "outside the field of performance and examine [it] as a social activity, a sexual ritual, a form of self-expression, a kind of exercise, and a way of speaking through the body" : as fabrication.

The fabricators of the fabrications are not left out of this wellrounded volume. "Handmaidens of the Glamour Culture: Costumers in the Hollywood Studio System" by Elizabeth Nielsen precedes and preludes Jane Gaines' "Costume and Narrative : How Dress Tells the Woman's Story". The former is a sociohistorical study of the (mostly) women behind the scenes who produce the clothing for the stage. It is a familiar tale of the garment manufacturing industry : the kind and organization of the work, long hours and backbreaking physical strains, meager pay with no social benefits, inequitable gender relations and the rise of the union (Local 705). But the studios "could then count on the loyalty of these workers because of the degree of personal satisfaction they found in their jobs which became the "intrinsic reward" for 25 years of low pay, low status, and backbreaking work" (172). Gaines picks up this theme and examines the art in the task, the special talent of the Hollywood designer. She brings the reader back to the adjacent terrain of the construction of the female image by those who specialize in precisely that. What 
story does the wardrobe tell? How must costume interact with narrative? What are the criteria of a successful costume? So skilfully must the costume be constructed in colour, line, design and fabric, that it is thoroughly identified with the body and becomes unnoticeable. A costume may clash with the narrative and claim undue attention, or it may be ineffectual. Ideally it collaborates with its wearer, with the scene, and with the narrative. The master clothing designer is a master, inevitably, in the interpretation of character, narrative, and reactions of the viewer.

The comprehensive bibliography (278-294) thematically arranged into sections on "Hollywood Costumes", "Fashion / Body / Consumer Culture" and "Feminism and Cultural Studies" contributes another useful entry to an already useable volume.

Sandra Niessen

University of Alberta 